\title{
Physiological response of three wild castor bean (Ricinus communis L.) ecotypes exposed to different substrate moisture levels
}

\author{
Peña-Uribe, Gabriel de J. ${ }^{1 *}$; Vázquez-Ghun, Garolina ${ }^{1}$; Valdez-Cepeda, Ricardo D. ${ }^{2}$; \\ Armendáriz-Erives, Sigifredo ${ }^{1}$; López-Santos, A. ${ }^{{ }^{*}}$ \\ 1 Universidad Autónoma Chapingo, Unidad Regional Universitaria de Zonas Áridas, Bermejillo, Durango, \\ México, C. P. 35230. \\ 2 Universidad Autónoma Chapingo, Centro Regional Universitario Centro Norte, Morelos, Zacatecas, C. P. \\ 98053. \\ * Correspondence: biol.mar.gabriel@gmail.com; alopez@chapingo.uruza.edu.mx
}

Gitation: Peña-Uribe, G. de J., Vázquez-Chun, C., Valdez-Cepeda, R. D., Armendáriz-Erives, S., \& López-Santos, A. (2022). Physiological response of three wild castor bean (Ricinus communis L.) ecotypes exposed to different substrate moisture levels. Agro Productividad. https://doi.org/10.32854/ agrop.v15il.2045

Editor in Chief: Dr. Jorge Cadena Iñiguez

Received: May 23, 2021.

Accepted: January 3, 2022.

Published on-line: February 5, 2022

Agro Productividad, 15(1). January. 2022. pp: 111-119.

This work is licensed under a Creative Commons Attribution-NonCommercial 4.0 International license.

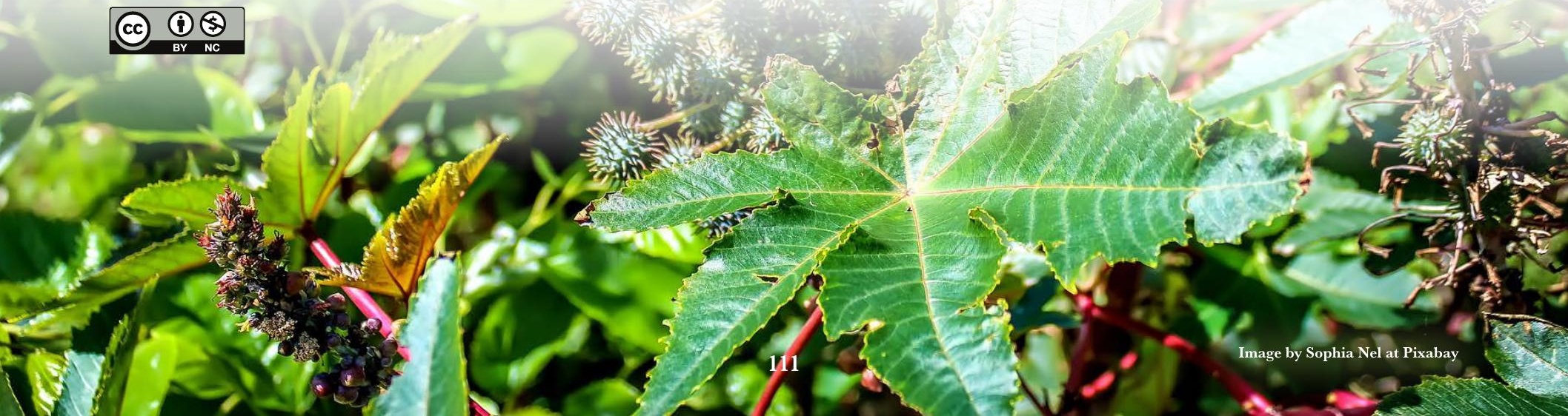

\section{ABSTRACT}

Objective: To analyze the morphological and physiological responses of three wild castor bean (Ricinus communis L.) ecotypes to four different gravimetric moisture levels.

Design/methodology/approach: The wild castor bean ecotype seeds were collected in the arid region of the State of Durango, Mexico. Three potential ecotypes were selected according to seed size and shape. A completely random greenhouse culture was established with three wild castor bean ecotypes; they were planted in substrate with four gravimetric moisture levels $\left(\mathrm{T} 1_{\Theta}=24 \pm 2 \% ; \mathrm{T} 2_{\Theta}=20 \pm 2 \% ; \mathrm{T} 3_{\Theta}=16 \pm 2 \% ; \mathrm{T} 4_{\Theta}=14 \pm 2 \%\right)$. The physiological measurements were carried out with LICOR's LI-6400XT portable photosynthesis system. A two-way ANOVA was conducted to obtain differences between the factors and their interactions.

Results: Ecotypes 1 and 2 had larger stems and leaves than ecotype 3. The differences in plant growth due to the effects of a $24 \%$ and $20 \%$ gravimetric moisture content were not significant $(\mathrm{p}=0.05)$. Ecotype 3 presented the highest photosynthetic rate $\left(14.77 \pm 6.14 \mu \mathrm{mol} \mathrm{CO}_{2} \mathrm{~m}^{-2} \mathrm{~s}^{-1}\right)$; however, the differences between ecotypes were not significant. The differences were determined based mainly on substrate moisture.

Study limitations/implications: Determining the water requirements of castor bean crops allows for the optimization of water use in regions where this resource is scarce.

Findings/conclusions: Ecotype 1 seeds - which were very large, very round, and had low eccentricity — are associated with plants that have larger and wider stems and leaves. This genotype could be domesticated considering a substrate moisture content of $24 \%$ and $20 \%$.

Key words: Intracellular carbon dioxide, Leaf vapor pressure deficit, Morphometry, Photosynthetic rate, Stomatal conductance.

\section{INTRODUCTION}

The seeds of castor bean (Ricinus communis L.) (Euphorbiaceae) are used to produce castor oil, which is widely used in the chemical industry (Severino et al., 2012; Lakhani et al., 2015). The characteristics of its oil have made castor bean a non-food crop of great 
economic importance in the last few years (Severino et al., 2012). In addition, various authors (Da Silva et al., 2006; Dos Santos et al., 2017; Buendía-Tamariz et al., 2018) emphasize the fact that castor oil is a high-quality raw material to produce biofuel. Smallscale producers, mainly from India, China, Brazil, and Mozambique, account for 96\% of the worldwide castor bean seed production (Severino and Alud, 2013). Only in 2008 did Mexico figure as the eighth castor bean producer worldwide; afterwards, production data have decreased (FAOSTAT, 2021). Although the demand for castor oil is constantly increasing, the supply is limited by the current production of castor bean, which cannot satisfy the global market's demand (Severino et al., 2012).

Limited water availability is a recurring phenomenon and a main restricting factor in crop productivity in the arid tropics (Vijaya-Kumar et al., 2005; Sausen and Rosa, 2010). Castor bean's tolerance to water deficit has been studied from diverse viewpoints. Different authors (Dai et al., 1992; Lacerda et al., 2009; Sausen and Rosa, 2010; Brito-Pinto et al., 2014; Dos Santos et al., 2017) agree that castor bean has high tolerance levels to water deficit and can even have a low seed yield with little available water, a situation where other species could not be cultivated (Severino et al., 2012). Nevertheless, castor bean cultivation is still unknown in different regions of Mexico, which reduces its promotion and the development of crop systems (Buendía-Tamariz et al., 2018).

Establishing the water requirements of castor bean cultivation allows for the optimization of water use in regions where this resource is scarce. Although castor bean is considered a species with low genetic diversity (Allan et al., 2008; Foster et al., 2010), it has a high phenotypic polymorphism, from very tall to very small plants (Lakhani et al., 2015). Therefore, there might be significant differences in morphometric and physiological responses among castor bean ecotypes at different gravimetric moisture levels. The aim was to analyze the morphologic and physiological responses of three castor bean ecotypes collected in the arid regions of the State of Durango, Mexico, based on four soil moisture content levels. The underlying hypothesis was that ecotypes have different morphometric and physiological responses to different substrate gravimetric moisture levels.

\section{MATERIALS AND METHODS}

This research was conducted between June 2017 and May 2018 under greenhouse conditions at the Unidad Regional Universitaria de Zonas Áridas de la Universidad Autónoma Chapingo $\left(25.893^{\circ} \mathrm{N}, 103.600^{\circ} \mathrm{W}\right)$. The climate in the region is very arid and semi-hot, with an annual average temperature between $18^{\circ} \mathrm{C}$ and $22^{\circ} \mathrm{C}$ (BWhw). Temperatures inside the greenhouse fluctuated between 3.9 and $36.09{ }^{\circ} \mathrm{C}$, with an overall average of $25.07 \pm 6.2{ }^{\circ} \mathrm{C}$ (Table 1 ).

\section{Preparation for the experiment}

The wild castor bean seeds were collected in the arid region of the State of Durango, Mexico (Table 2). Three potential seed ecotypes were selected according to size and shape (data are not shown). The first group comprised large seeds with lower eccentricity and higher roundness (Ecotype 1). The second group included medium-sized seeds, with high eccentricity, and intermediate roundness (Ecotype 2). The third group consisted of small 
Table 1. Mean environmental conditions in the greenhouse during the experiment.

\begin{tabular}{c|l|c|c|c|c}
\hline \multirow{3}{*}{ Year } & \multicolumn{1}{|c|}{ Month } & \multicolumn{3}{c|}{ Min.T. } & \multicolumn{2}{c|}{ Max.T. } & Mean T. & \multirow{2}{*}{$\begin{array}{c}\text { Hum. } \\
\text { (\%) }\end{array}$} \\
\cline { 3 - 6 } & July & 24.31 & 40.63 & 31.36 & 39.81 \\
\hline & August & 23.22 & 43.67 & 32.13 & 40.59 \\
\cline { 2 - 6 } 2017 & September & 20.89 & 39.77 & 28.9 & 43.97 \\
\cline { 2 - 6 } & October & 16.7 & 41.1 & 26.51 & 42.73 \\
\cline { 2 - 6 } & November & 11.33 & 41.18 & 23.16 & 33.07 \\
\cline { 2 - 6 } & December & 8.34 & 29.08 & 16.21 & 54.59 \\
\hline \multirow{3}{*}{2018} & January & 5.89 & 32.86 & 16.53 & 38.76 \\
\cline { 2 - 6 } & February & 13.84 & 38.2 & 23.58 & 44.11 \\
\cline { 2 - 6 } & March & 15.92 & 43.72 & 27.76 & 36.06 \\
\cline { 2 - 6 } & April & 18.36 & 43.1 & 28.65 & 36.02 \\
\cline { 2 - 6 } & May & 20.8 & 43.56 & 30.15 & 37.9 \\
\hline
\end{tabular}

Min.T., minimum temperature; Max.T., maximum temperature; MeanT., mean temperature; and Hum., Air humidity.

seeds with highly dispersed eccentricity and roundness values (Ecotype 3). Out of each group, 36 seeds were selected. They were planted in 72-cell seedbeds with peat moss substrate. The seedbeds were irrigated daily with purified water until transplant day. The seedlings were transplanted 21 days after planting, when they had already developed two leaves.

The substrate that was used in the experiment came from soil collected in an experimental plot. According to the World Reference Base for Soil Resources (IUSS Working Group WRB, 2015), the soil was identified as aridic Calcisol (CLad). In addition, the soil was characterized in the laboratory following the Norma Oficial Mexicana NOM021-RECNAT-2000 guidelines, which establish specifications for soil fertility, salinity, and classification. Bulk density was determined with the paraffin method (AS-03); soil texture

Table 2. Collection sites of castor ecotypes and their environmental characteristics.

\begin{tabular}{|c|c|c|c|c|c|c|}
\hline Eco & Site & Lat. & Long. & WRB Key & RSG & Glimate \\
\hline E3 & Gómez Palacio & 25.613726 & -103.4932 & $\mathrm{SNszw}+\mathrm{LV}$ sow/3 & SOLONETZ & BWhw \\
\hline E1 & Guatimape & 24.807201 & -104.9197 & SNaxszn+VRmzszp/2 & SOLONETZ & BSlkw \\
\hline E3 & Leandro Valle & 25.086666 & -105.065 & FLeu+KSlvcc/1 & FLUVISOL & BSohw \\
\hline E1 & Nazareno & 25.397986 & -103.4201 & RGsowca+CLad+VRcrca/2 & REGOSOL & BWhw \\
\hline E2 & Nazas & 25.228944 & -104.113 & CLlv + KSlvcc/2 & CALCISOL & BWhw \\
\hline E2 & Nazas & 25.232055 & -104.1168 & CLlv+KSlvcc/2 & CALCISOL & BWhw \\
\hline E2 & Nazas & 25.2306944 & -104.1371 & FLeu+KSlvcc/1 & FLUVISOL & BWhw \\
\hline E1 & San Luis del Cordero & 26.196666 & -105.2017 & CLskptp+RGskca/2R & CALCISOL & BWhw \\
\hline E3 & Villa Unión & 23.967611 & -104.0496 & Flca+KSvpcn/2 & FLUVISOL & BS $1 \mathrm{kw}$ \\
\hline E3 & Villa Unión & 23.9595 & -104.0539 & Flca+KSvpcn/2 & FLUVISOL & BSlkw \\
\hline
\end{tabular}

Eco, ecotype; WRB Key, World Reference Base for Soil Resources key; and RSG, reference soil group. 
was established using the Bouyoucos hydrometer method (AS-09); the AS-05 method was used to determine soil moisture; organic matter was established with the Walkley and Black method (AS-07); and electric conductivity was measured using the AS-16 method. Soil texture was identified as sandy clay loam (Table 3).

\section{Experimental design}

Twelve treatments were established based on the three castor bean ecotypes and four gravimetric moisture levels $\left(\mathrm{T} 1_{\ominus}=24 \pm 2 \% ; \mathrm{T} 2_{\ominus}=20 \pm 2 \% ; \mathrm{T} 3_{\ominus}=16 \pm 2 \% ; \mathrm{T} 4_{\Theta}=14 \pm 2 \%\right)$. Four repetitions were prepared, giving a total of 48 pots or experimental units. Six kilograms of dry soil were placed in each of the forty-eight 7.5-liter pots. One liter of tap water was added to each pot in order to dampen the substrate. Then a castor bean seedling was placed in each pot. All pots were labelled with the relevant ecotype, the corresponding gravimetric moisture percentage, and the repetition number. The treatments were distributed according to a completely random experimental design.

\section{Irrigation}

Water for irrigation was extracted from a deep well. Water electric conductivity was $2.85 \mathrm{dS} \mathrm{m} \mathrm{m}^{-1}$ according to the Orion Star A222 portable conductivity meter (Thermo Scientific, USA). During a 30-day acclimatization period, plant irrigation was homogenous: approximately $900 \mathrm{~g}$ of water were added per pot. Subsequently, pots were weighed every two days before and after irrigation, in order to estimate the quantity of water to be restored.

\section{Morphological variables}

Plants were measured every week throughout the experiment. A measuring tape was used to measure the stem height $(\mathrm{SH})$ - from the substrate base to the last internode. To measure the stem width (SW), a permanent marker was first used to make a mark on the stem $1 \mathrm{~cm}$ above the soil surface. This mark served as a reference to measure the stem width using a Vernier caliper. Leaf length (LL) and leaf width (LW) were measured and the results were used to calculate the leaf area (LA).

\section{Physiological variables}

A LI-6400XT portable photosynthesis system (LICOR Inc., Lincoln, Nebraska, USA) was used to measure the physiological response of the three castor bean ecotype plants to the different substrate moisture levels. Once all the plants had at least one leaf with a length of over $5 \mathrm{~cm}$, measurements were done every 15 days. The LI-6400XT was calibrated with

Table 3. Biophysical characteristics of aridic Calcisol collected from the experimental plot.

\begin{tabular}{|c|c|c|c|c|c|c|c|c|c|c|}
\hline \multirow{2}{*}{ Sample } & \multirow{2}{*}{$\begin{array}{c}\text { BD } \\
\mathrm{g} \mathrm{cm}^{-3}\end{array}$} & FG & PWP & USM & OC & OM & \multirow{2}{*}{ pH } & \multirow{2}{*}{$\begin{array}{c}\text { EC } \\
\mathrm{dS} \mathrm{m} \mathrm{m}^{-1}\end{array}$} & $\mathbf{N}$ & $\mathrm{CO}_{3}$ \\
\hline & & \multicolumn{5}{|c|}{$\%$} & & & \multicolumn{2}{|c|}{$\%$} \\
\hline Depth (cm) & \multirow{2}{*}{1.28} & \multirow{2}{*}{27.24} & \multirow{2}{*}{14.63} & \multirow{2}{*}{12.6} & \multirow{2}{*}{0.23} & \multirow{2}{*}{0.4} & \multirow{2}{*}{8} & \multirow{2}{*}{7.72} & \multirow{2}{*}{0.1} & \multirow{2}{*}{7.3} \\
\hline 0 a 15 & & & & & & & & & & \\
\hline
\end{tabular}

BD, bulk density; FC, field capacity; PWP, permanent wilting point; USM, usable soil moisture; OC, organic carbon; $\mathrm{OM}$, organic material; $\mathrm{pH}$, hydrogen potential; $\mathrm{EC}$, electric conductivity; $\mathrm{N}$, nitrogen; and $\mathrm{CO}_{3}$, carbonates. 
a photon flux density within the photosynthetically active radiation spectrum of $1000 \mu \mathrm{mol}$ $\mathrm{m}^{-2} \mathrm{~s}^{-1}$. This device was used to estimate photosynthetic rate $\left(A\right.$ in $\left.\mu \mathrm{mol} \mathrm{CO}_{2} \mathrm{~m}^{-2} \mathrm{~s}^{-1}\right)$, stomatal conductance ( $g s$ in $\left.\mathrm{mol} \mathrm{H}_{2} \mathrm{O} \mathrm{m}^{-2} \mathrm{~s}^{-1}\right)$, intracellular carbon dioxide concentration ( $\mathrm{C} i$ in $\mu \mathrm{mol} \mathrm{CO}_{2} \mathrm{~mol}^{-1}$ ), leaf water vapor deficit (VpdL in $\mathrm{kPa}$ ), and leaf temperature (Tleaf in ${ }^{\circ} \mathrm{C}$ ).

\section{Statistical analyses}

Morphological and physiological variables were subjected to normality tests. Variables that presented a non-normal distribution were standardized. Two-way ANOVAs were conducted to identify the effects of the different factors on the response variables. When the results allowed the identification of significant effects of the factors, Tukey's test was applied to conduct the corresponding comparisons. Statistical analyses were conducted with the MiniTab 17 software (MiniTab Inc., USA).

\section{RESULTS AND DISGUSSION}

\section{Morphometry}

The most striking results are described in the rest of this section. Ecotype 1 and 2 plants had the tallest stems, which were especially similar when cultivated in substrates with 24\% and 20\% gravimetric moisture levels (Table 4). In addition, ecotype 1 plants had the widest stems when the substrate had a gravimetric moisture level of 24\%. Ecotype 1 and 2 plants also had the longest and widest leaves when grown in substrates with $24 \%$ and $20 \%$ gravimetric moisture levels. Significantly, ecotype 1 plants had the largest leaf area, especially when cultivated in substrates with a gravimetric moisture content of $24 \%$.

In general, these results are consistent with those reported by Brum et al. (2011), who found that castor bean seedlings grown from heavier seeds emerge faster and are taller than seedlings grown from lighter seeds. Other authors (e.g., Lacerda et al., 2009; Silva et al., 2009; Brito-Pinto et al., 2014) emphasized that, if water availability increases, the height, leaf area, and yield of castor bean plants also increases. It is worth mentioning that plants were smaller than the "Al Guarany 2002" variety $(59.3 \mathrm{~cm})$, according to Brito-Pinto

Table 4. Means and standard deviations of castor bean morphometric variables grouped by factors.

\begin{tabular}{|c|c|c|c|c|c|}
\hline Factors & Stem height $(\mathrm{cm})$ & Stem width $(\mathrm{cm})$ & Leaf length $(\mathrm{cm})$ & Leaf width $(\mathrm{cm})$ & Leaf area $\left(\mathrm{cm}^{2}\right)$ \\
\hline \multicolumn{6}{|l|}{ Ecotype } \\
\hline $\mathrm{E} 2$ & $8.51 \pm 2.57^{\mathrm{B}}$ & $0.58 \pm 0.19^{\mathrm{B}}$ & $6.75 \pm 2.13^{\mathrm{A}}$ & $8.31 \pm 2.39^{\mathrm{AB}}$ & $60.89 \pm 34.46^{\mathrm{A}}$ \\
\hline E3 & $7.46 \pm 2.34^{\mathrm{C}}$ & $0.53 \pm 0.18^{\mathrm{B}}$ & $5.45 \pm 1.84^{\mathrm{B}}$ & $7.23 \pm 1.99^{\mathrm{B}}$ & $44.08 \pm 23.97^{\mathrm{B}}$ \\
\hline $\mathrm{T}_{\Theta} 24 \pm 2 \%$ & $10.91 \pm 4.56^{\mathrm{A}}$ & $0.74 \pm 0.22^{\mathrm{A}}$ & $7.52 \pm 2.44^{\mathrm{A}}$ & $9.52 \pm 2.48^{\mathrm{A}}$ & $76.63 \pm 42.25^{\mathrm{A}}$ \\
\hline $\mathrm{T} 2_{\Theta} 20 \pm 2 \%$ & $9.93 \pm 3.36^{\mathrm{A}}$ & $0.62 \pm 0.17^{\mathrm{B}}$ & $6.88 \pm 1.59^{\mathrm{A}}$ & $8.59 \pm 1.75^{\mathrm{A}}$ & $60.87 \pm 23.98^{\mathrm{B}}$ \\
\hline $\mathrm{T} 3_{\ominus} 16 \pm 2 \%$ & $8.74 \pm 2.51^{\mathrm{B}}$ & $0.51 \pm 0.12^{\mathrm{C}}$ & $5.34 \pm 1.61^{\mathrm{B}}$ & $6.84 \pm 3.33^{\mathrm{B}}$ & $39.30 \pm 23.65^{\mathrm{C}}$ \\
\hline $\mathrm{T} 4_{\ominus} 14 \pm 2 \%$ & $6.63 \pm 2.31^{\mathrm{C}}$ & $0.36 \pm 0.09^{\mathrm{D}}$ & $4.89 \pm 1.52^{\mathrm{B}}$ & $5.78 \pm 1.17^{\mathrm{B}}$ & $34.99 \pm 12.87^{\mathrm{C}}$ \\
\hline
\end{tabular}

Results of Tukey's means tests are shown, capital letters represent similar groups. 
et al. (2014). This could be explained by pot size: Brito-Pinto et al. (2014) used 30-L pots (four times larger than the ones we used in our work). However, the leaf area of our three ecotypes is larger than the leaf area of the "Al Guarany 2002" variety $\left(35.37 \mathrm{~cm}^{2}\right)$. Leaf area is an important factor, because it is directly related to the leaf's capacity to intercept light and carry out photosynthesis (Severino and Auld, 2013).

\section{Physiology}

The results for the physiological variables were as follows: only the leaves of ecotype 2 and 3 plants had a higher gs than genotype 1 (Table 5). Likewise, the lower gs is associated to the leaves of plants that were cultivated in the substrate with the lowest gravimetric moisture level (16\%); their temperature and photosynthetic rate were also considerably lower than those of the leaves of plants in substrates with higher moisture content levels. However, the differences between $A, C i, V p d L$, and Tleaf variable values for leaves of the three ecotypes were statistically similar. Likewise, the leaves of plants cultivated in the two lower substrate moisture levels presented higher water vapor deficits than those associated to a substrate gravimetric moisture level of $25 \%$.

Overall, plants cultivated in pots with a higher substrate moisture level presented higher physiological activity values. This is consistent with reports by other authors (Lacerda $e t$ al., 2009; Silva et al., 2009; Brito-Pinto et al., 2014), who mention that castor bean yields are closely related to the available moisture. According to Da Matta et al. (2001), values for $\mathrm{A}$ in plants with the highest available moisture levels are similar to those of bean (16.3 $\left.\mu \mathrm{mol} \mathrm{CO} 2 \mathrm{~m}^{-2} \mathrm{~s}^{-1}\right)$ and eucalyptus $\left(14.4 \mu \mathrm{mol} \mathrm{CO}_{2} \mathrm{~m}^{-2} \mathrm{~s}^{-1}\right)$. Moreover, Sausen and Rosa (2010) obtained maximum photosynthesis values of $15 \mu \mathrm{mol} \mathrm{CO} \mathrm{Cm}^{-2} \mathrm{~s}^{-1}$ with $18 \%$ of soil moisture, while Dos Santos et al. (2017) recorded maximum photosynthesis values of 16.2 $\mu \mathrm{mol} \mathrm{CO}_{2} \mathrm{~m}^{-2} \mathrm{~s}^{-1}$.

On the one hand, different authors (Lawlor and Tezara, 2009; Broeckx et al., 2014; Dos Santos et al., 2017) maintain that the decrease of $g s$ is a result of stomatal closure, which is a key phenomenon and the first defense against dehydration; this might have been the

Table 5. Means and standard deviations of the physiological variables of castor bean grouped by factors.

\begin{tabular}{|c|c|c|c|c|c|}
\hline $\begin{array}{l}\text { Variables } \\
\text { Factors }\end{array}$ & $\boldsymbol{A}$ & gs & Ci & $V p d L$ & Tleaf \\
\hline \multicolumn{6}{|l|}{ Ecotype } \\
\hline 1 & $11.11 \pm 5.32$ & $0.10 \pm 0.07^{\mathrm{B}}$ & $147.33 \pm 53.88$ & $2.66 \pm 0.72$ & $31.14 \pm 3.42$ \\
\hline 2 & $12.93 \pm 5.66$ & $0.12 \pm 0.11^{\mathrm{AB}}$ & $127.70 \pm 149.40$ & $2.85 \pm 0.86$ & $32.43 \pm 3.36$ \\
\hline 3 & $14.77 \pm 6.14$ & $0.16 \pm 0.12^{\mathrm{A}}$ & $154.90 \pm 73.00$ & $2.84 \pm 0.97$ & $32.81 \pm 3.32$ \\
\hline \multicolumn{6}{|c|}{ Substrate Moisture } \\
\hline $\mathrm{Tl}_{\ominus} 24 \pm 2 \%$ & $14.95 \pm 5.61^{\mathrm{A}}$ & $0.14 \pm 0.11^{\mathrm{A}}$ & $127.60 \pm 132.00$ & $3.00 \pm 0.96^{\mathrm{A}}$ & $33.36 \pm 3.17^{\mathrm{A}}$ \\
\hline $\mathrm{T} 2_{\ominus} 20 \pm 2 \%$ & $13.22 \pm 5.21^{\mathrm{A}}$ & $0.14 \pm 0.11^{\mathrm{A}}$ & $149.38 \pm 73.50$ & $2.68 \pm 0.81^{\mathrm{AB}}$ & $31.81 \pm 3.30^{\mathrm{B}}$ \\
\hline $\mathrm{T} 3_{\ominus} 16 \pm 2 \%$ & $7.62 \pm 4.10^{\mathrm{B}}$ & $0.06 \pm 0.04^{\mathrm{B}}$ & $161.11 \pm 57.03$ & $2.51 \pm 0.52^{\mathrm{B}}$ & $29.90 \pm 3.04^{\mathrm{C}}$ \\
\hline
\end{tabular}

A, photosynthetic rate $\left(\mu \mathrm{mol} \mathrm{CO}_{2} \mathrm{~m}^{-2} \mathrm{~s}^{-1}\right)$; gs, stomatal conductance $\left(\mathrm{mol} \mathrm{H}_{2} \mathrm{O} \mathrm{m}^{-2} \mathrm{~s}^{-1}\right)$; $\mathrm{Ci}$, intracelular carbon dioxide concentration $\left(\mu \mathrm{mol} \mathrm{CO} \mathrm{mol}^{-1}\right) ; \mathrm{VdpL}$, leaf water vapor deficit $(\mathrm{kPa})$; and Tleaf temperatura foliar $\left({ }^{\circ} \mathrm{C}\right)$. Results of Tukey's means tests are shown, capital letters represent similar groups. 
case of the plants subjected to a substrate gravimetric moisture level of $16 \%$. Furthermore, according to Heckenberger et al. (1998) and de Freitas et al. (2011), this decrease in stomatal conductance might also be the result of a decrease in the stomatal conductance values of castor bean plants subjected to water deficit, as a consequence of the low stomata density during leaf growth in water stress conditions.

On the other hand, the tendency of $A$ to decrease and $C i$ to increase as the soil moisture availability decreases is noticeable (Table 4). The increase in $C i$ is inconsistent with reports by Ocheltree et al. (2014), who maintain that the reduction in the plants' stomatal conductance also entails a reduction in the $\mathrm{CO}_{2}$ diffusion rate and the internal $\mathrm{CO}_{2}$ concentration. This situation can reduce the efficiency of carbon fixation in plants. In light of this, the responses of plants to water deficit seem to be complex and to involve adaptive changes and genotype influence (Chaves et al., 2002).

Barbour and Buckley (2007) and other authors mention that an increase in leaf water vapor deficit directly affects stomatal closure. Nevertheless, this was not observed on castor bean leaves. Oddly enough, the highest $V p d L$ was observed in plants that were grown in pots with higher substrate moisture levels, which were also those with higher gs. This is consistent with Davies and Zang (1991), who maintain that stomatal response is frequently associated with soil water content, rather than with leaf water status. Therefore, this could mean that the plant can transpire continually without problems, which allows water to move constantly through the plant. According to several authors (McDonald et al., 2002; Snyder et al., 2003), this can provide more benefits for the plant, such as a better nutrient absorption from the soil.

\section{CONGLUSIONS}

Castor bean ecotype 1 has big, very round seeds with low eccentricity, which yielded plants with wide stems, with a $24 \%$ substrate gravimetric moisture level. This ecotype's plants are also associated with very long and wide leaves, when they are grown in substrates with $24 \%$ and $20 \%$ gravimetric moisture levels. Notably, castor bean ecotype 1 plants had the larger leaf area, especially when cultivated in substrates with a $24 \%$ gravimetric moisture content. In general, results indicate that this genotype could be introduced in an improvement program, considering these two substrates gravimetric moisture content conditions for its cultivation.

\section{ACKNOWLEDGEMENTS}

G.J.P.-U. is extremely grateful for the PhD grant (CVU 514128) awarded to him by the Consejo Nacional de Ciencia y Tecnología (CoNaCyT). The authors are indebted to the Universidad Autónoma Chapingo for the funding of the project "Potencialidades de la higuerilla como un cultivo alternativo en el norte de México para la adaptación y mitigación al cambio climático" (Castor bean's potential as an alternative crop in northern Mexico for climate change adaptation and mitigation)(Clave E-07-2016).

\section{REFERENGES}

Allan, G., Williams, A., Rabinowicz, P. D., Chan, A. P., Ravel, J., \& Keim, P. (2008). Worldwide genotyping of castor bean germplasm (Ricinus communis L.) using AFLPs and SSRs. Genet. Resour. Crop Evol. 55: 365-378. doi:10.1007/s10722-007-9244-3 
Barbour, M.M., \& Buckley, T.N. (2007). The stomatal response to evaporative demand persists at night in Ricinus communis plants with high nocturnal conductance. Plant, Cell and Environment. 30: 711-721. doi: 10.1111/j.1365-3040.2007.01658.x

Brito-Pinto, M.A., Reisser-Júnior, C., Carlos-Timm, L., Franke-Brixner, G., dos Anjos e Silva, S.D., \& HelwingPenning, L. (2014). Development and initial growth of castor bean (Ricinus communis) crop submitted to different soil water tensions. Agrociencia 48: 501-510.

Broeckx, L.S., Fichot, R., Verlinden, M.S., \& Ceulemans, R. (2014). Seasonal variations in photosynthesis, intrinsic water-use efficiency and stable isotope composition of poplar leaves in a short-rotation plantation. Tree Physiol. 34: 1-14. doi:10.1093/treephys/tpu057

Brum, B., Lopes, S.J., Storck, L., Lúcio, A.D., Oliveira, P.H., Milani, M., (2011). Canonical correlation between variables seed, seedling, plant and grain yield in castor bean. Ciênc. Rural. 41: 404-411. doi: 10.1590/S0103-84782011000300007

Buendía-Tamariz, M.N., Trejo-Calzada, R., Sánchez-Cohen, I., Flores-Hernández, A., López-Santiago, M.A., \& Pedroza-Sandoval, A. (2018). Growth analysis of four varieties of Ricinus communis L. in an arid region of México. Interciencia Journal. 43: 457-479.

Chaves, M.M., Pereira, J.S., Maroco, J, Rodríguez, M.L., Ricardo, C.P.P., Osorio, M.L., Carvalho, I., Faria, T., \& Pinheiro C. (2002). How plants cope with water stress in the field. Photosynthesis and growth. Annals of Botany. 89: 907-916. doi: 10.1093/aob/mcf105

Da Silva, N.D.L., Maciel, M.R.W., Batistella, C.B., \& Maciel-Filho, R. (2006). Optimization of biodiesel production from castor oil. Appl. Biochem. Biotechnol. 130: 405-414. doi: 10.1385/ABAB:130:1:405

Da Matta, F., Loos, R.A., Rodrigues, R., \& Barros, E. (2001). Actual and Potential Photosynthetic Rates of Tropical Crop Species. Bras. Fisiol. Veg. 13: 24-32. doi:10.1590/s0103-31312001000100003

Dai, z., Edwards, G.E., \& Ku, M.S.B. (1992). Control of Photosynthesis and Stomatal Conductance in Ricinus communis L. (Castor Bean) by Leaf to Air Vapor Pressure Deficit. Plant Physiol. 99: 1426-1434. doi: 10.1104/pp.99.4.1426

Davies, W.J. \& Zhang, J. (1991) Root signals and the regulation of growth and development of plants in drying soil. Annual Review of Plant Physiology and Plant Molecular Biology 42: 55-76. doi: 10.1146/annurev. pp.42.060191.000415

de Freitas G.A.S., de Silva, A.R.A., da Bezerra, F.M.L., Lacerda, G.F., de Pereira-Filho, J.V., \& de Sousa, G.G. (2011). Produção de matéria seca e trocas gasosas em cultivares de mamoneira sob níveis de irrigação. Revista Brasileira de Engenharia Agricola e Ambiental, 15: 1168-1174. doi: 10.1590/S141543662011001100009

Dos Santos, G.M., Endres, L., Ferreira, V.M., Silva, J.V., Rolim, E.V., \& Wanderley-Filho, H.C.L., (2017). Photosynthetic Capacity and Water use Efficiency in Ricinus communis (L.) under Drought Stress in Semi-Humid and Semi-Arid Areas. Annals of the Brazilian Academy of Sciences 89: 3015-3029. doi:10.1590/0001-3765201720160729

Foster, J. T., Allan, G. J., Chan, A. P., Rabinowicz, P. D., Ravel, J., Jackson, P. J., \& Keim, P. (2010). Single nucleotide polymorphisms for assessing genetic diversity in castor bean (Ricinus communis). BMC Plant Biol. 10:13. doi: 10.1186/1471-2229-10-13

Hecknenberger, U., Roggatz, U., Schurr, U. (1998) Effect of drought stress on the cytological status in Ricinus communis. Journal of Experimental Botany 49: 181-189.

Lacerda, R. D., Guerra, H.O.C., \& Júnior, G.B. (2009). Influência do déficit hídrico e da matéria orgânica do solo no crescimento e desenvolvimento da mamoneira BRS 188-Paraguaçu. Rev. Bras. Ciencia Agrar. 4: 440-447.

Lakhani, H.N., Patel, S.V., Bodar N.P., \& Golakiya B.A. (2015). RAPD analysis of genetic diversity of castor bean (Ricinus communis L.). Int.J.Curr.Microbiol.App.Sci. 4: 696-703.

Lawlor, D.W., \& Tezara, W. (2009). Causes of decreased photosynthetic rate and metabolic capacity in waterdeficient leaf cells: a critical evaluation of mechanisms and integration of processes. Ann Bot. 103: 561-579. doi:10.1093/aob/mcn244

McDonald, E.P., Erickson, J.E., \& Kruger, E.L. (2002). Can decreased transpiration limit plant nutrient acquisition in elevated $\mathrm{CO}_{2}$ ? Functional Plant Biology. 29: 1115-1120. doi: 10.1071/FP02007

Ocheltree, T., Nippert, J., \& Prasad, P. (2014). Stomatal responses to changes in vapor pressure deficit reflect tissue-specific differences in hydraulic conductance. Plant Cell Environ. 37: 132-139. doi: 10.1111/ pce. 12137

Sausen, T.L., \& Rosa, L.M.G. (2010). Growth and carbon assimilation limitations in Ricinus communis (Euphorbiaceae) under soil water stress conditions. Acta Botanica Brasilica. 24: 648-654. doi: 10.1590/ S0102-33062010000300008 
Severino, L.S., Auld, D.L., Baldanzi, M., Cândido, M.J., Chen, G., Crosby, W., \& Lavanya, G. (2012). A review on the challenges for increased production of castor. Agronomy journal 104: 853-880. doi: 10.2134/agronj2011.0210

Severino, L.S., \& Auld, D.L. (2013). A framework for the study of the growth and development of castor plant. Industrial Crops and Products 46: 25-38. doi: 10.1016/j.indcrop.2013.01.006

Silva, S.M.S., Gheyi, H.R., Beltrão, N.E.M., dos Santos, J.W., \& Soares, F.A.L. (2009). Dotações hídricas em densidades de plantas na cultura da mamoneira cv. BRS Energia. Rev. Bras. Ciencia Agrar. 4: 338-348.

Snyder, K.A., Richards, J.H., \& Donovan, L.A. (2003). Night-time conductance in C3 and C4 species: do plants lose water at night? Journal of Experimental Botany. 54: 861-865. doi: 10.1093/jxb/erg082

Vijaya-Kumar, P., Ramakrishna, Y., Bhaskara-Rao, D., Sridhar, G., Srinivasa-Rao, G., \& Rao, G. (2005). Use of remote sensing for drought stress monitoring, yield prediction and varietal evaluation in castor beans (Ricinus communis L.). International Journal of Remote Sensing, 26: 5525-5534. doi: 10.1080/01431160500285258 